\title{
Article \\ Comparison of Plant Morphology, Yield and Nutritional Quality of Fagopyrum esculentum and Fagopyrum tataricum Grown under Field Conditions in Belgium
}

\author{
Lauranne Aubert ${ }^{1}$, Christian Decamps ${ }^{1}$, Guillaume Jacquemin ${ }^{2}$ and Muriel Quinet ${ }^{1, *}$ (D) \\ 1 Earth and Life Institute-Agronomy, Université Catholique de Louvain, B-1348 Louvain-la-Neuve, Belgium; \\ lauranne.aubert@uclouvain.be (L.A.); christian.decamps@uclouvain.be (C.D.) \\ 2 Unité Productions Végétales, Département Productions Agricoles, Centre Wallon de Recherches \\ Agronomiques, B-5030 Gembloux, Belgium; g.jacquemin@cra.wallonie.be \\ * Correspondence: muriel.quinet@uclouvain.be; Tel.: +32-10-47-34-43
}

Citation: Aubert, L.; Decamps, C.; Jacquemin, G.; Quinet, M. Comparison of Plant Morphology, Yield and Nutritional Quality of Fagopyrum esculentum and Fagopyrum tataricum Grown under Field Conditions in Belgium. Plants 2021, 10, 258. https://doi.org/10.3390/ plants10020258

Academic Editor: Mateja Germ Received: 24 December 2020

Accepted: 23 January 2021

Published: 28 January 2021

Publisher's Note: MDPI stays neutral with regard to jurisdictional claims in published maps and institutional affiliations.

Copyright: (c) 2021 by the authors. Licensee MDPI, Basel, Switzerland. This article is an open access article distributed under the terms and conditions of the Creative Commons Attribution (CC BY) license (https:/ / creativecommons.org/licenses/by/ $4.0 /)$.

\begin{abstract}
Buckwheat is a pseudocereal with high nutritional and nutraceutical properties. Although common buckwheat (Fagopyrum esculentum) is the main cultivated species, Tartary buckwheat (Fagopyrum tataricum) is gaining interest. In this paper, we compared plant growth, yield-related parameters and seed nutritional qualities of two varieties of F. esculentum and F. tataricum under field conditions in Belgium. Fagopyrum esculentum flowered earlier, produced less nodes, less branches, less inflorescences, but more flowers per inflorescence than F. tataricum. The yield was higher in F. tataricum, while the thousand-grain weight was higher in F. esculentum. Yield ranged between $2037 \mathrm{~kg} / \mathrm{ha}$ and $3667 \mathrm{~kg} / \mathrm{ha}$ depending on the species and year. Regarding nutritional qualities, seeds of $F$. esculentum contained more proteins $(15.4 \%$ vs. $12.8 \%)$ than seeds of $F$. tataricum although their amino acid profile was similar. Seeds of F. esculentum contained also more $\mathrm{Mg}$ (1.36 vs. $1.15 \mathrm{mg} / \mathrm{g}$ dry weight (DW)) and less Fe (22.9 vs. $32.6 \mu \mathrm{g} / \mathrm{g}$ DW) and Zn (19.6 vs. $24.5 \mu \mathrm{g} / \mathrm{g} \mathrm{DW})$ than F. tataricum. The main difference between seed nutritional quality was the concentration of flavonoids that was 60 times higher in F. tataricum than in F. esculentum. Both species grow well under Belgian conditions and showed good seed quality.
\end{abstract}

Keywords: common buckweat; Tartary buckweat; proteins; amino acids; minerals; yield; seed

\section{Introduction}

Buckwheat is a dicotyledon belonging to the Polygonaceae family and the Fagopyrum genus [1]. Inside this genus, two species are cultivated, Fagopyrum esculentum Moench (common buckwheat) and Fagopyrum tataricum (L.) Gaertn (Tartary buckwheat) [2]. The former accounts for $90 \%$ of the world buckwheat production. Both species originated from China [3,4]. Fagopyrum esculentum may have been cultivated for as long as 6000 years, and the Yunnan region of China has been shown to be a significant site of domestication of common buckwheat [3]. From southern China, common buckwheat was introduced to Asian countries through two main routes, via Himalayan region and Tibet or via northern China and Japan [4,5]. It has been suggested that buckwheat was introduced in Europe during the period 4000-2800 BP but it did not become a popular crop until the Late Medieval period $[3,4,6]$. From the 17 th century, buckwheat was introduced to America and South Africa by emigrants [3,4]. Fagopyrum tataricum originates from the Himalayan region and has been cultivated for at least 4000 years [7]. It grows wild in China, Siberia, Tibet, Kashmir and northern Pakistan [3] and two independent domestication events occurred in southwestern and northern China [7]. It was introduced to other countries from northern China [7]. Buckwheat is considered as a pseudocereal, such as amaranth (Amaranthus spp.) and quinoa (Chenopodium quinoa Willd) [3,8]. Pseudocereals are dicotyledonous crops that are not related to the cereals; however, their seeds do share similarities with 
cereal grains [9]. Their seeds have similar physical appearance and contain high starch content similar to true cereals [10]. However, the anatomy of the pseudocereal grains differs from the staple cereals in that they contain less endosperm and a higher proportion of embryos [8]. Pseudocereal grains have also high nutritional and nutraceutical qualities; however, despite their potential advantages, their agronomic potential remains poorly characterized $[8,10,11]$. Buckwheat is widely distributed in the world but grows for the most part in the northern hemisphere [9]. The largest producing countries of buckwheat are China, Russian Federation, Ukraine and France [12]. The world production in 2019 was 1.6 megatons cultivated on 1.7 mega ha [12]. Buckwheat remains thus a marginal crop compared to cereals. For example, maize (Zea mays L.) and wheat (Triticum sp. L.) productions were, respectively, 1148 and 766 megatons worldwide in 2019 [12]. In 2018, buckwheat yield ranged from 0.4 tons per ha in South Africa to 3.3 tons per ha in France with a mean world yield of 0.94 tons per ha [12]. Buckwheat species have strong adaptability to adverse environmental conditions and represent a good opportunity for organic farming $[3,4,13,14]$. In most western European countries, buckwheat production has declined during the 20th century with the development of more productive crops, but it is currently receiving renewed attention for its nutritional and environmentally friendly qualities [4,15-17].

Buckwheat is used for food consumption, mainly as flour or groats [9]. It is also used to produce noodles, porridge, bread, pancakes, sprouts for salads and smoothies, and even drinks [18]. Buckwheat is considered to have high nutritional value and medicinal qualities and its benefits have been highlighted in several reviews [2,4,9,10,18-22]. Buckwheat is known to be gluten-free which makes it interesting for people with celiac disease [20]. It contains a well-balanced amino acid composition with high concentrations of lysine and arginine compared to cereals $[20,23]$. It is also rich in dietary fibers, minerals and vitamins [20]. Finally, buckwheat contains high concentrations of antioxidants such as polyphenols and flavonoids [9]. The potential health benefits of buckwheat consumption include anticancer, anti-inflammatory, hypoglycemic, and hypocholesterolemic activities, which are presumably associated with health-promoting compounds such as proteins and phenolic compounds $[9,22,24,25]$. These qualities have increased buckwheat demand in recent years and have attracted the attention of food scientists and their research [21,22].

It is well known that environmental conditions and agricultural practices may affect the nutritional qualities of crops [26,27]. In this paper, we compared plant growth, yieldrelated parameters and seed nutritional qualities of two varieties of F. esculentum and $F$. tataricum under field conditions in Belgium. The selected varieties were La Harpe and Darja for F. esculentum and Islek and Zlata for F. tartaricum. La Harpe is a French variety that was previously grown under field conditions in Belgium [28], and Darja is an important variety cultivated in Slovenia [29]. Islek is a domestic population from the Islek region of Europe (border region of Luxemburg, Germany and Belgium) [21,30], and Zlata is a Slovenian variety [31].

\section{Results}

Fagopyrum esculentum var. Darja and var. La Harpe and Fagopyrum tataricum var. Islek and var. Zlata were sown under field conditions in Belgium, respectively, on 22 May 2019 and 7 June 2020. Seed density was $37 \mathrm{~kg} / \mathrm{ha}$ for F. esculentum $\left(1.48-1.35 \times 10^{6}\right.$ seeds/ha for var. Darja, 1.23-1.02 × 10 $0^{6}$ seeds/ha for var. La Harpe in 2019 and 2020, respectively) and $30 \mathrm{~kg} / \mathrm{ha}$ for $F$. tataricum $\left(1.56-1.55 \times 10^{6}\right.$ seeds/ha for var. Islek and $1.45-1.40 \times 10^{6}$ seeds/ha for var. Zlata in 2019 and 2020, respectively). Harvest took place, respectively, on 17 September 2019 and 11 September 2020. Weather conditions during buckwheat cultivation are presented in Figure S1. In 2019, the mean daily temperature was $18.1 \pm 3.6^{\circ} \mathrm{C}$ with a minimum temperature of $6.7^{\circ} \mathrm{C}$ and a maximum temperature of $39.6^{\circ} \mathrm{C}$. The mean daily rainfall was $1.8 \pm 5.8 \mathrm{~mm}$ with 69 days without rain and two dry periods (22 June-11 July and 19 August-15 September) and a maximum of $42 \mathrm{~mm}$ of rainfall on 27 July. The mean daily irradiance was $1.8 \pm 0.5 \mathrm{KWh} / \mathrm{m}^{2} \mathrm{~d}$ with a minimum of 
$0.3 \mathrm{KWh} / \mathrm{m}^{2} \mathrm{~d}$ and a maximum of $2.8 \mathrm{KWh} / \mathrm{m}^{2} \mathrm{~d}$ and a total irradiance of $177 \mathrm{KWh} / \mathrm{m}^{2}$ over the growing season. In 2020, the mean daily temperature was $18.6 \pm 3.7^{\circ} \mathrm{C}$ with a minimum temperature of $8.7^{\circ} \mathrm{C}$ and a maximum temperature of $34.9^{\circ} \mathrm{C}$. The mean daily rainfall was $1.4 \pm 3.6 \mathrm{~mm}$ with 56 days without rain and one dry period from 8 July to 12 August and a maximum of $27 \mathrm{~mm}$ of rainfall on 18 August. A drought period of 22 days without rain occurred before sowing in 2020 (Figure S1). In 2020, the mean daily irradiance was $1.8 \pm 0.6 \mathrm{KWh} / \mathrm{m}^{2} \mathrm{~d}$ with a minimum of $0.6 \mathrm{KWh} / \mathrm{m}^{2} \mathrm{~d}$ and a maximum of $2.9 \mathrm{KWh} / \mathrm{m}^{2} \mathrm{~d}$ and a total irradiance of $210 \mathrm{KWh} / \mathrm{m}^{2}$ over the growing season. The sum of the daily average temperature (base 8) to harvest was $1374{ }^{\circ} \mathrm{C}$ in 2019 and $1199{ }^{\circ} \mathrm{C}$ in 2020 . The sum of precipitations from sowing to harvest was $214 \mathrm{~mm}$ in 2019 and $156 \mathrm{~mm}$ in 2020 .

\subsection{Plant Morphology}

Both species differed regarding plant architecture and reproductive growth (Table 1). Globally, F. esculentum showed a smaller plant height $\left(\mathrm{F}_{1,24}=5.34, p=0.029\right)$, produced less nodes on the main stem $\left(\mathrm{F}_{1,37}=46.1, p<0.001\right)$ and less branches $\left(\mathrm{F}_{1,37}=12.9, p<0.001\right)$ than $F$. tataricum. Regarding reproductive growth, F. esculentum flowered before $F$. tataricum $\left(\mathrm{F}_{1,37}=24.7, p<0.001\right)$. Fagopyrum tataricum produced more inflorescences per plant than F. esculentum $\left(\mathrm{F}_{1,37}=24.6, p<0.001\right)$ but with fewer flowers per inflorescence $\left(\mathrm{F}_{1,37}=115.23, p<0.001\right)$. The seeds of $F$. esculentum were also larger than the ones of F. tataricum $\left(\mathrm{F}_{1,18}=23.9, p=0.001\right)$.

Table 1. Vegetative, reproductive and yield-related parameters of F. esculentum and F. tataricum under field conditions in 2019 .

\begin{tabular}{|c|c|c|c|c|c|}
\hline \multirow[b]{2}{*}{ Parameter } & \multirow[b]{2}{*}{$\mathbf{n}$} & \multicolumn{2}{|c|}{ F. esculentum } & \multicolumn{2}{|c|}{ F. tataricum } \\
\hline & & Darja & La Harpe & Islek & Zlata \\
\hline \multicolumn{6}{|c|}{ Vegetative Growth } \\
\hline Plant height $(\mathrm{cm})$ & 10 & $137.6 \pm 10.2 \mathrm{a}$ & $98 \pm 13.1 \mathrm{~b}$ & $126 \pm 16.8 \mathrm{a}$ & $139.1 \pm 18.6 \mathrm{a}$ \\
\hline Number of leaves & 10 & $58.7 \pm 27.2 \mathrm{a}$ & $30.5 \pm 5.6 b$ & $36.4 \pm 25.9 \mathrm{ab}$ & $50.7 \pm 33.3 \mathrm{ab}$ \\
\hline Number of branches & 10 & $5.2 \pm 0.8 \mathrm{~b}$ & $4.4 \pm 1 \mathrm{~b}$ & $6.7 \pm 1 \mathrm{a}$ & $5.5 \pm 1.3 \mathrm{ab}$ \\
\hline Number of nodes & 10 & $15 \pm 2.3 b$ & $10.8 \pm 3.4 c$ & $20.1 \pm 2.3 \mathrm{a}$ & $20.4 \pm 3.4 \mathrm{a}$ \\
\hline Stem dry weight (g) & 5 & $7.1 \pm 2.7 \mathrm{a}$ & $6.5 \pm 1.9 \mathrm{a}$ & $4.8 \pm 1.4 \mathrm{a}$ & $5.3 \pm 1.4 \mathrm{a}$ \\
\hline Leaves dry weight (g) & 5 & $0.9 \pm 0.3 \mathrm{a}$ & $1.2 \pm 0.4 \mathrm{a}$ & $0.3 \pm 0.2 \mathrm{a}$ & $0.8 \pm 0.8 \mathrm{a}$ \\
\hline \multicolumn{6}{|c|}{ Reproductive Growth } \\
\hline Node of the first inflorescence & 10 & $6.3 \pm 0.8 \mathrm{bc}$ & $5.5 \pm 1.2 \mathrm{c}$ & $7.9 \pm 1 \mathrm{a}$ & $7.2 \pm 0.8 \mathrm{ab}$ \\
\hline Number of inflorescences & 10 & $69.1 \pm 18 \mathrm{ab}$ & $45.2 \pm 21.1 \mathrm{~b}$ & $89 \pm 40.5 \mathrm{ab}$ & $107.6 \pm 63.3 \mathrm{a}$ \\
\hline Inflorescence dry weight (g) & 5 & $1.6 \pm 0.8 \mathrm{~b}$ & $18.1 \pm 5.2 \mathrm{a}$ & $8.4 \pm 3 \mathrm{ab}$ & $6.2 \pm 1.5 \mathrm{ab}$ \\
\hline Flowers per inflorescence & 10 & $73.7 \pm 20.2 \mathrm{~b}$ & $108.5 \pm 27 \mathrm{a}$ & $29.3 \pm 5.5 c$ & $31.1 \pm 5.8 c$ \\
\hline Viable seeds per inflorescence & 10 & $7.5 \pm 2.2 c$ & $35.8 \pm 10.4 \mathrm{a}$ & $11.5 \pm 3.1 \mathrm{bc}$ & $17 \pm 3.9 \mathrm{~b}$ \\
\hline Aborted seeds per inflorescence & 10 & $3.3 \pm 2.6 b$ & $15 \pm 10.2 \mathrm{a}$ & $4.6 \pm 2.7 \mathrm{~b}$ & $3.4 \pm 2 \mathrm{~b}$ \\
\hline Seed set $(\%)$ & 10 & $10.8 \pm 3.3 c$ & $33.3 \pm 5.4 b$ & $38.8 \pm 4.5 b$ & $51.5 \pm 5 \mathrm{a}$ \\
\hline Thousand-grain weight (g) & 5 & $27.5 \pm 0.4 b$ & $36.1 \pm 4.7 \mathrm{a}$ & $19.3 \pm 0.7 c$ & $21.4 \pm 0.8 \mathrm{bc}$ \\
\hline
\end{tabular}

We also observed strong differences between varieties. In F. esculentum, the plants of var. La Harpe were $28 \%$ smaller $\left(\mathrm{F}_{1,10}=31.4, p<0.001\right)$, produced $48 \%$ less leaves $\left(\mathrm{F}_{1,10}=16.2, p<0.001\right)$ and $12 \%$ less inflorescences $\left(\mathrm{F}_{1,10}=6.4, p=0.021\right)$ than plants of var. Darja. However, they produced $46 \%$ more flowers $\left(\mathrm{F}_{1,10}=44.9, p=0.003\right)$ and five times more seeds $\left(\mathrm{F}_{1,10}=76.5, p<0.001\right)$ per inflorescence than var. Darja (Table 1$)$. The seed set was three times higher in var. La Harpe than in var. Darja $\left(\mathrm{F}_{1,10}=76.5, p<0.001\right)$ and the thousand-grain weight was $26 \%$ higher in the former than in the latter $\left(\mathrm{F}_{1,4}=9.95\right.$, $p=0.0 .34$, Table 1). We observed less difference among varieties of $F$. tataricum than of F. esculentum. Vegetative growth and reproductive growth parameters were indeed similar in var. Islek and var. Zlata (Table 1$)$ with the exception of the seed weight $\left(F_{1,4}=12.01\right.$, $p=0.03)$ and the seed set $\left(\mathrm{F}_{1,10}=82.3, p=0.009\right)$, which were slightly higher in var. Zlata than in var. Islek. 
The obtained yield was $2370 \mathrm{~kg} / \mathrm{ha}$ in var. Darja and $2778 \mathrm{~kg} / \mathrm{ha}$ in var. La Harpe of F. esculentum in 2019 , while it was $2444 \mathrm{~kg} / \mathrm{ha}$ in var. Islek and $3667 \mathrm{~kg} / \mathrm{ha}$ in var. Zlata of F. tataricum. In 2020, the yield was, respectively, $2371 \mathrm{~kg} / \mathrm{ha}, 2037 \mathrm{~kg} / \mathrm{ha}, 2518 \mathrm{~kg} / \mathrm{ha}$ and $2260 \mathrm{~kg} / \mathrm{ha}$ in var. Darja, var. La Harpe, var. Islek and var. Zlata. In 2020, the mean thousand grain weight was $25.0 \mathrm{~g}$ in var. Darja, $30.4 \mathrm{~g}$ in var. La Harpe, $19.4 \mathrm{~g}$ in var. Islek and $20.8 \mathrm{~g}$ in var. Zlata.

\subsection{Nutritional Qualities}

A principal component analysis (PCA) was performed in order to identify potential differences between species and varieties regarding nutritional qualities of seeds (Figure 1). The PCA showed that $42 \%$ of the variance was explained by axis 1 (Dim1) and $16 \%$ by axis 2 (Dim2). Axis 1 was mainly explained by, on one side, the protein content, and on the other side, the amino acid, $\mathrm{Zn}$ and Fe and flavonoid concentrations (Figure 1a). Axis 2 was mainly explained by, on one side, the seed weight, and on the other side, the total flavonoid and polyphenol concentrations (Figure 1a). Figure 1b showed a clear separation between varieties and species.

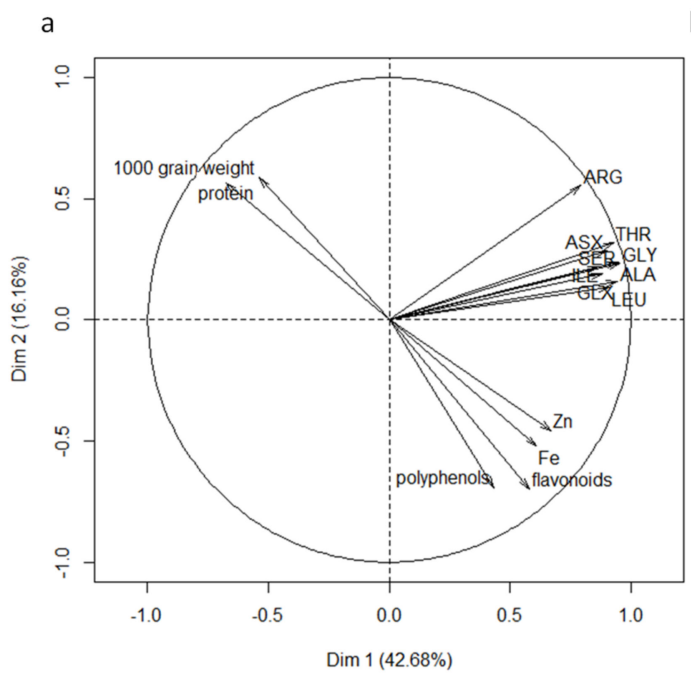

b

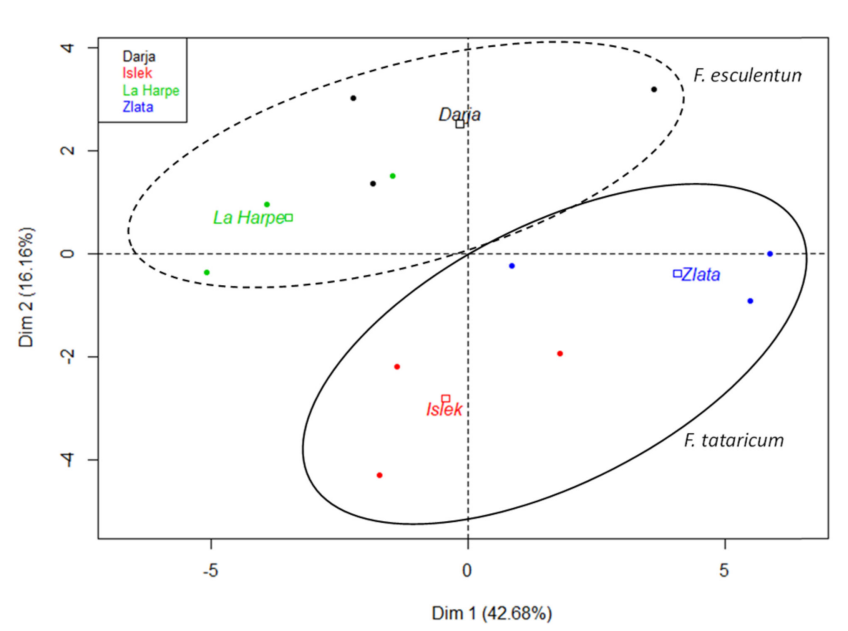

Figure 1. Principal component analysis (PCA) of seed nutritional parameters of F. esculentum (var. Darja and var. La Harpe) and F. tataricum (var. Islek and var. Zlata) grown under field conditions in Belgium. (a) Variable graph of PCA showing nutritional parameter (only parameters with $\cos ^{2}>0.6$ were shown). (b) Individual graph showing the varieties of $F$. esculentum and F. tataricum.

The protein content was higher in F. esculentum than in F. tataricum $\left(\mathrm{F}_{1,10}=16.7\right.$, $p=0.002$ ) while the total amino acid concentration was similar in both species (Table 2). The essential amino acid percentage was around $31 \%$ and $28 \%$, respectively, in F. esculentum and F. tataricum. It has to be noticed that tryptophan, which is an essential amino acid, could not be quantified with the used technique. The main amino acids were glutamine + glutamic acid and arginine in both species. The amino acid profile did not differ between species, with the exception of tyrosine, which was more present in F. tataricum than in F. esculentum $\left(\mathrm{F}_{1,10}=6.35, p=0.030\right)$. Regarding differences among varieties, methionine concentration was higher in var. Zlata than in var. Islek in F. tataricum $\left(\mathrm{F}_{1,4}=22.23, p=0.009\right.$, Table 2). The concentrations of alanine $\left(\mathrm{F}_{3,8}=3.95, p=0.049\right)$ and leucine $\left(\mathrm{F}_{3.8}=4.24, p=0.045\right)$ were higher in var. Zlata than in var. La Harpe (Table 2).

Regarding mineral content, the seeds of F. esculentum contained more $\mathrm{Mg}\left(\mathrm{F}_{1,18}=7.83\right.$, $p=0.005)$ and less $\mathrm{Na}\left(\mathrm{F}_{1,18}=7.26, p=0.0158\right), \mathrm{Fe}\left(\mathrm{F}_{1,18}=17.26, p=0.0007\right)$ and $\mathrm{Zn}$ $\left(\mathrm{F}_{1,18}=7.88, p=0.0116\right)$ than the ones of F. tataricum, but the concentrations of $\mathrm{K}, \mathrm{Ca}$ and $\mathrm{Cu}$ were similar whatever the species (Table 3). The highest concentration of $\mathrm{Na}$ was observed in var. Islek and the lowest in var. La Harpe, while the highest concentrations of 
Fe and $\mathrm{Zn}$ was observed in var. Zlata and the lowest in var. Darja. Seeds of var. La Harpe were richer in $\mathrm{Mg}$ than in the other varieties $\left(\mathrm{F}_{3,16}=8.15, p=0.002\right)$.

Table 2. Protein and amino acid concentrations in seeds of F. esculentum and F. tataricum.

\begin{tabular}{|c|c|c|c|c|c|}
\hline \multirow[b]{2}{*}{ Parameter } & \multirow[b]{2}{*}{$\mathbf{n}$} & \multicolumn{2}{|c|}{ F. esculentum } & \multicolumn{2}{|c|}{ F. tataricum } \\
\hline & & Darja & La Harpe & Islek & Zlata \\
\hline Protein content $(\%)$ & 3 & $14.6 \pm 1.3 \mathrm{ab}$ & $16.1 \pm 1.2 \mathrm{a}$ & $12.8 \pm 0.1 b$ & $12.8 \pm 0.9 \mathrm{~b}$ \\
\hline \multicolumn{6}{|c|}{ Amino acid concentrations (mg/g FW) } \\
\hline Asparagine ${ }^{1}$ & 3 & $7.87 \pm 0.37 a$ & $7.03 \pm 0.51 \mathrm{a}$ & $7.47 \pm 0.50 \mathrm{a}$ & $8.17 \pm 0.32 \mathrm{a}$ \\
\hline Cysteine & 3 & $2.00 \pm 0.61 \mathrm{a}$ & $1.97 \pm 0.15 \mathrm{a}$ & $2.10 \pm 0.10 \mathrm{a}$ & $2.40 \pm 0.26 \mathrm{a}$ \\
\hline Glutamine $^{2}$ & 3 & $18.41 \pm 1.82 \mathrm{a}$ & $16.62 \pm 1.36 \mathrm{a}$ & $17.52 \pm 1.20 \mathrm{a}$ & $20.18 \pm 0.90 a$ \\
\hline Serine & 3 & $4.88 \pm 0.36 \mathrm{a}$ & $4.67 \pm 0.14 \mathrm{a}$ & $4.77 \pm 0.13 \mathrm{a}$ & $4.95 \pm 0.31 \mathrm{a}$ \\
\hline Histidine $^{3}$ & 3 & $2.22 \pm 0.16 \mathrm{a}$ & $2.17 \pm 0.14 \mathrm{a}$ & $2.05 \pm 0.10 \mathrm{a}$ & $2.17 \pm 0.15 \mathrm{a}$ \\
\hline Glycine & 3 & $6.90 \pm 0.49 a$ & $6.37 \pm 0.33 a$ & $6.60 \pm 0.30 a$ & $7.23 \pm 0.42 a$ \\
\hline Threonine $^{3}$ & 3 & $4.42 \pm 0.33 \mathrm{a}$ & $4.00 \pm 0.28 \mathrm{a}$ & $4.13 \pm 0.19 a$ & $4.58 \pm 0.50 \mathrm{a}$ \\
\hline Arginine & 3 & $10.37 \pm 0.90 \mathrm{a}$ & $9.48 \pm 0.36 \mathrm{a}$ & $9.25 \pm 0.31 \mathrm{a}$ & $10.48 \pm 0.50 \mathrm{a}$ \\
\hline Methionine ${ }^{3,4}$ & 3 & $1.60 \pm 0.46 \mathrm{ab}$ & $1.47 \pm 0.42 \mathrm{ab}$ & $0.90 \pm 0.35 b$ & $2.03 \pm 0.23 \mathrm{a}$ \\
\hline Alanine & 3 & $5.22 \pm 0.36 \mathrm{ab}$ & $4.82 \pm 0.20 \mathrm{~b}$ & $5.02 \pm 0.24 \mathrm{ab}$ & $5.53 \pm 0.25 a$ \\
\hline Tyrosine & 3 & $1.77 \pm 0.12 b$ & $1.87 \pm 0.23 b$ & $2.07 \pm 0.15 \mathrm{a}$ & $2.00 \pm 0.10 \mathrm{a}$ \\
\hline Valine ${ }^{3}$ & 3 & $3.20 \pm 0.26 \mathrm{a}$ & $2.92 \pm 0.38 a$ & $3.45 \pm 0.13 a$ & $3.18 \pm 0.16 a$ \\
\hline Phenylalanine ${ }^{3}$ & & $3.8 \pm 0.21 \mathrm{a}$ & $3.5 \pm 0.21 \mathrm{a}$ & ND & ND \\
\hline Isoleucine ${ }^{3}$ & 3 & $2.68 \pm 0.17 \mathrm{a}$ & $2.55 \pm 0.73 \mathrm{a}$ & $2.63 \pm 0.10 \mathrm{a}$ & $2.83 \pm 0.13 \mathrm{a}$ \\
\hline Leucine ${ }^{3}$ & 3 & $5.85 \pm 0.35 \mathrm{ab}$ & $5.37 \pm 0.37 b$ & $5.72 \pm 0.32 \mathrm{ab}$ & $6.4 \pm 0.33 a$ \\
\hline Lysine $^{3}$ & 3 & $2.87 \pm 0.24 \mathrm{a}$ & $3.00 \pm 0.40 \mathrm{a}$ & $2.83 \pm 0.16 \mathrm{a}$ & $3.80 \pm 0.99 a$ \\
\hline Proline & 3 & $2.30 \pm 0.26 \mathrm{a}$ & $1.73 \pm 0.15 \mathrm{a}$ & $1.93 \pm 0.11 \mathrm{a}$ & $2.40 \pm 0.66 \mathrm{a}$ \\
\hline
\end{tabular}

${ }^{1}$ Asparagine + aspartic acid; ${ }^{2}$ glutamine + glutamic acid; ${ }^{3}$ essential amino acids; ${ }^{4}$ methionine sulfone; ND: no data; FW: fresh weight.

Table 3. Mineral concentrations in seeds of F. esculentum and F. tataricum.

\begin{tabular}{cccccc}
\hline & & \multicolumn{2}{c}{ F. esculentum } & \multicolumn{2}{c}{ F. tataricum } \\
Mineral & $\mathbf{n}$ & Darja & La Harpe & Islek & Zlata \\
\hline $\mathrm{K}(\mathrm{mg} / \mathrm{g} \mathrm{DW})$ & 5 & $3.72 \pm 0.48 \mathrm{a}$ & $4.58 \pm 0.24 \mathrm{a}$ & $4.16 \pm 0.13 \mathrm{a}$ & $4.37 \pm 0.90 \mathrm{a}$ \\
$\mathrm{Na}(\mathrm{mg} / \mathrm{g} \mathrm{DW})$ & 5 & $1.86 \pm 0.65 \mathrm{ab}$ & $1.10 \pm 0.32 \mathrm{~b}$ & $2.54 \pm 1.08 \mathrm{a}$ & $2.36 \pm 0.60 \mathrm{ab}$ \\
$\mathrm{Ca}(\mathrm{mg} / \mathrm{g} \mathrm{DW})$ & 5 & $0.16 \pm 0.09 \mathrm{a}$ & $0.22 \pm 0.07 \mathrm{a}$ & $0.21 \pm 0.04 \mathrm{a}$ & $0.11 \pm 0.04 \mathrm{a}$ \\
$\mathrm{Mg}(\mathrm{mg} / \mathrm{g} \mathrm{DW})$ & 5 & $1.22 \pm 0.17 \mathrm{~b}$ & $1.50 \pm 0.12 \mathrm{a}$ & $1.17 \pm 0.07 \mathrm{~b}$ & $1.13 \pm 0.08 \mathrm{~b}$ \\
$\mathrm{Cu}(\mu \mathrm{g} / \mathrm{g} \mathrm{DW})$ & 5 & $6.57 \pm 1.74 \mathrm{a}$ & $5.82 \pm 0.95 \mathrm{a}$ & $6.75 \pm 0.60 \mathrm{a}$ & $5.88 \pm 1.38 \mathrm{a}$ \\
$\mathrm{Fe}(\mu \mathrm{g} / \mathrm{g} \mathrm{DW})^{3}$ & 5 & $19.90 \pm 2.33 \mathrm{~b}$ & $25.94 \pm 3.05 \mathrm{ab}$ & $30.51 \pm 4.21 \mathrm{ab}$ & $34.66 \pm 5.01 \mathrm{a}$ \\
$\mathrm{Zn}(\mu \mathrm{g} / \mathrm{g} \mathrm{DW})$ & 5 & $18.14 \pm 3.06 \mathrm{~b}$ & $21.17 \pm 2.80 \mathrm{ab}$ & $22.85 \pm 1.88 \mathrm{ab}$ & $26.17 \pm 4.80 \mathrm{a}$ \\
\hline
\end{tabular}

DW: dry weight.

The main difference between buckwheat species regarding seed quality concerned the antioxidant content (Table 4$)$. The total concentrations of polyphenols $\left(\mathrm{F}_{1,10}=7.41\right.$, $p=0.006)$ and flavonoids $\left(\mathrm{F}_{1,10}=8.3, p=0.004\right)$ were, respectively, 1.5 and 60 times higher in F. tataricum than in F. esculentum. Although there was no difference between varieties of a same species for the total polyphenol content, the total flavonoids content was higher in the seeds of var. Darja than in the ones of var. La Harpe in F. esculentum $\left(\mathrm{F}_{1,40}=11.7\right.$, $p=0.026)$.

Table 4. Antioxidant concentrations in seeds of F. esculentum and F. tataricum.

\begin{tabular}{lccccc}
\hline & & \multicolumn{2}{c}{ F. esculentum } & \multicolumn{2}{c}{ F. tataricum } \\
\multicolumn{1}{c}{ Antioxidant } & n & Darja & La Harpe & Islek & Zlata \\
\hline Flavonoids $(\mathrm{mg} / \mathrm{g} \mathrm{FW})$ & 3 & $0.10 \pm 0.03 \mathrm{~b}$ & $0.02 \pm 0.01 \mathrm{~b}$ & $3,44 \pm 103 \mathrm{a}$ & $3,79 \pm 105 \mathrm{a}$ \\
Polyphenols (mg/g FW) & 3 & $3.00 \pm 0.13 \mathrm{~b}$ & $3.25 \pm 0.17 \mathrm{ab}$ & $4.48 \pm 1.07 \mathrm{ab}$ & $4.90 \pm 0.34 \mathrm{a}$ \\
\hline FW: fresh weight. & \multicolumn{4}{c}{}
\end{tabular}




\section{Discussion}

Two varieties of F. esculentum and of F. tataricum were compared under field conditions and the nutritional qualities of the harvested seeds were analyzed. Both species differed in their architecture mainly regarding the number of branches, the number of inflorescences per plant, the number of flowers per inflorescence and the seed weight. Fagopyrum tataricum was described as smaller and slenderer with seeds $40 \%$ smaller than F. esculentum [3]. The main differences between the buckwheat species are related to plant reproduction. Fagopyrum esculentum is self-incompatible, distylous and depends on insect pollination for fertilization and seed production [32,33]. Fagopyrum tataricum produces smaller flowers that are homostylous and self-compatible and does not depend on insect pollination to produce seeds [33]. Such difference may explain the higher seed set and yield observed in F. tataricum than in F. esculentum. It was previously observed that the yield of F. tataricum was higher than in F. esculentum and it was suggested to be explained by the selfing of F. tataricum [21]. In our growing conditions, the yield ranged between $2037 \mathrm{~kg} / \mathrm{ha}$ and $3667 \mathrm{~kg} / \mathrm{ha}$ depending on the species and year. In previous works in the same region, yields ranged between 2000 and $2500 \mathrm{~kg} /$ ha for F. esculentum var. La Harpe [28], which are in agreement with our results. These yields are higher than the worldwide and European average over the last 5 years for F. esculentum that were, respectively, $1034 \mathrm{~kg} / \mathrm{ha}$ and $1068 \mathrm{~kg} / \mathrm{ha}$ [12]. The average buckwheat yield of the European Union over the last 5 years was about $1797 \mathrm{~kg} / \mathrm{ha}$ and ranged from $3411 \mathrm{~kg} / \mathrm{ha}$ in France to $798 \mathrm{~kg} / \mathrm{ha}$ in Estonia [12]. The yields we obtained for F. esculentum in our study were thus similar to the most productive European countries. Although the observed yields were lower than those obtained in France [12], they were similar to those obtained in Czech Republic [12] or Serbia [34]. In western Europe, buckwheat is often cultivated in poor soils or marginal area since it can grow under a variety of climatic conditions in a wide range of soils $[15,17,35]$. In our experiment, buckwheat was cultivated in loamy soil with high yield potential, which could partly explain the high yields we obtained. We observed that the yield was maintained despite the hot and dry periods that occurred in summer in Belgium over these last few years. However, meteorological parameters were shown to significantly affect buckwheat yields and drought and high temperature could decrease average yield [15,36]. Although both species could be affected by drought and heat stress mainly regarding reproductive growth, it was shown that they develop resistance mechanisms and that $F$. tataricum was less affected by water stress than F. esculentum $[13,14]$. Under stressful periods, the long-lasting flowering of buckwheat may be an advantage allowing compensation to maintain yield.

Buckwheat seeds are known to be rich in high quality carbohydrates, protein and amino acid, fatty acid, vitamins, minerals and bioactive compounds such as polyphenols [22]. However, the total content of components depends on variety or environmental factors $[2,15,36]$. We observed that both species differed by their protein and mineral content in the seeds (Figure 1). Seeds of F. esculentum contained more proteins than seeds of $F$. tataricum although their amino acid profile was similar at the exception of tyrosine. Seeds of F. esculentum contained also more $\mathrm{Mg}$ and less Fe and $\mathrm{Zn}$ than F. tataricum and flavonoid content was higher in the latter. Moreover, differences were observed between varieties regarding nutritive compound concentrations.

The total protein content we observed was similar to what was previously recorded in buckwheat and was higher than the protein content of cereals such as rice or maize [2,22]. It was reported that the protein content in F. esculentum and F. tataricum ranged from $6.4 \%$ to $18.9 \%$ depending on the species and environment $[2,22]$. The protein content of the seeds cultivated in Belgium was thus quite high as it ranged between 12.8 and 16.1\% in our experiment. When expressed as total protein produced per ha, we observed that var. Darja produced $346 \mathrm{~kg}$ protein $/ \mathrm{ha}$, var. La Harpe produced $447 \mathrm{~kg}$ protein/ha, var. Islek produced $312 \mathrm{~kg}$ protein/ha, and var. Zlata produced $469 \mathrm{~kg}$ protein/ha in 2019. The protein content also depends on the seed fraction: hull only contains $4 \%$ proteins while embryon contains $56 \%$ and buckwheat flour contains from $8.5 \%$ to $19 \%$ depending 
on the variety and growing conditions [2]. The protein content in flour of F. esculentum and F. tataricum was reported to be similar although it may differ among varieties [37]. Buckwheat proteins have high biological values although their digestibility is relatively low [18,37]. Regarding amino acid, buckwheat is mainly known for its balanced amino acid composition and its high level of lysine and arginine compared to cereals [2,11,18,22]. These amino acids are indeed generally limiting in cereals [11]. Arginine was the second most important amino acid detected in our experiment. The proportion of essential amino acid was around $30 \%$ in our experiment. The concentration of essential amino acid was similar between varieties at the exception of the concentration of methionine and leucine that did not differ between species but well among varieties. It was indeed reported that amino acid composition of F. esculentum and F. tataricum was rather similar $[18,21]$, as observed in our study. Ge and Wang [38] observed low ratio of lysine/arginine (0.79) and methionine/glycine (0.22) in Tartary buckwheat, arguing that these ratios are critical factors that determine the cholesterol-lowering effects of plant proteins and that the lower they are the better the cholesterol-lowering effects $[11,38]$. These ratios are indeed lower in buckwheat than in most plants [11]. In our experiment, we observed lysine/arginine ratios ranging between 0.27 and 0.36 and methionine/glycine ratios ranging from 0.14 to 0.28 depending on the variety. These results suggest a potential cholesterol lowering effect in both species.

Mineral elements are very abundant in buckwheat, particularly $\mathrm{K}, \mathrm{P}, \mathrm{Cu}, \mathrm{Ca}, \mathrm{Se}, \mathrm{Mg}$, $\mathrm{Ba}, \mathrm{B}, \mathrm{I}, \mathrm{Fe}, \mathrm{Pt}, \mathrm{Zn}$ and $\mathrm{Co}$ [22]. Buckwheat contains more $\mathrm{K}, \mathrm{Mg}, \mathrm{P}, \mathrm{Ca}, \mathrm{Fe}, \mathrm{Zn}, \mathrm{Cr}, \mathrm{Cu}$ and $\mathrm{Mn}$ than the main cereals [11,22]. Buckwheat could thus be an important source of microelements such as Fe, Mn and $\mathrm{Zn}$ [2]. Moreover, the bioavailability of $\mathrm{Zn}, \mathrm{Cu}$ and $\mathrm{K}$ from buckwheat is high compared to other crops [11]. We confirmed the high content of $\mathrm{K}$ and $\mathrm{Fe}$ in the seeds in our growing conditions. The seed mineral content observed in our growing conditions falls into the range of other studies for F. esculentum and F. tataricum [21,22]. It has to be noticed that mineral distribution in the seed depends on the tissues [21,22] and mineral proportion ranges from 2.0 to $2.5 \%$ in the whole grains, 1.8 to $2.0 \%$ in kernel, 2.2 to $3.5 \%$ in dehulled grains, 0.8 to $9 \%$ in flour and 3.4 to $4.2 \%$ in hulls [2,22]. We analyzed the minerals in the whole grains in this study. It was reported that $\mathrm{P}, \mathrm{K}$ and $\mathrm{Mg}$ are most concentrated in bran [2] and trace elements were excessively present in the outer membrane of seeds and seed coat [22]. However, Pongrac et al. showed that valuable essential elements such as $\mathrm{Mg}, \mathrm{P}, \mathrm{S}, \mathrm{K}, \mathrm{Mn}, \mathrm{Fe}$ and $\mathrm{Zn}$ are located in the embryo [18,39]. We also observed differences between buckwheat species regarding the concentration of $\mathrm{Mg}, \mathrm{Na}, \mathrm{Fe}$ and $\mathrm{Zn}$. A higher proportion of Fe and $\mathrm{Zn}$ in F. tataricum compared to F. esculentum was previously reported [21,22]. Moreover, mineral content may vary among varieties inside a same species as previously reported [21].

Seeds of both species contain polyphenols, and seeds of F. tataricum were particularly rich in flavonoids compared to F. esculentum. Such difference between species regarding total flavonoids content was not observed in other organs such as leaves and inflorescences in the same varieties $[13,14]$. The taste of F. tataricum seeds is more bitter than that of F. esculentum due to the higher concentrations of flavonoids [21]. Flavonoids are the prominent group of polyphenol secondary metabolites and rutin is the main flavonoid observed in buckwheat as it accounts for $90 \%$ of the total phenolics [22]. The content of polyphenols and flavonoids depends on various factors including plant growth stage, organ, species or growing season [22]. The content of flavonoids and of rutin in particular was reported to be usually higher in F. tataricum than in F. esculentum [21,22,37]. However, it varied among varieties in the same species [37]. Rutin content is lower in seeds of $F$. esculentum than in the other organs, and seeds of F. tataricum contain up to 70 times more rutin than the ones of F. esculentum [21,22]. On average, flour of F. tataricum contains 10 times more total flavonoid content than F. esculentum [21]. Rutin tends to prevent flour deterioration in buckwheat [18]. It is known that rutin content in the seed decreases during seed ripening and increases during seed germination so that rutin content in sprouts is significantly higher than in ungerminated seeds [22]. Buckwheat is the only grain crop with 
rutin content that is known to have antioxidant, anti-inflammatory, and anti-carcinogenic properties [11]. In addition to rutin, more than 130 major polyphenols have been isolated in buckwheat [21,22].

\section{Materials and Methods}

\subsection{Plant Material and Growth Conditions}

Seeds of Fagopyrum esculentum var. Darja and Fagopyrum tataricum var. Zlata were obtained from Prof. Dr. Ivan Kreft (University of Ljublana, Slovenia). Seeds of F. tataricum var. Islek were obtained from Christian Zewen (Luxemburg). Finally, seeds of F. esculentum var. La Harpe were purchased at GIRED (Le Thor, France).

Seeds were sowed at the experimental farm of the university (Corroy le Grand,

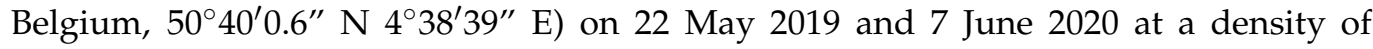
$37 \mathrm{~kg} / \mathrm{ha}$ for F. esculentum and of $30 \mathrm{~kg} / \mathrm{ha}$ for F. tataricum. It corresponds to a seed density of $1.48-1.35 \times 10^{6} /$ ha for var. Darja, $1.23-1.02 \times 10^{6} /$ ha for var. La Harpe, $1.56-1.55 \times 10^{6} /$ ha for var. Islek and 1.45-1.40 × 10 $/$ ha for var. Zlata in 2019 and 2020, respectively. Each variety occupied three lines of $6 \times 1.5 \mathrm{~m}$ organized in a split-plot design. Harvest occurred on 17 September in 2019 and 11 September in 2020. No fertilizers (N, $\mathrm{P}$ and $\mathrm{K}$ ) and pesticides were applied during the cultivation. Buckwheat was cultivated on a loamy soil, which characterized the region. A green manure (Avena strigosa) was cultivated before our field trial in 2019, and the buckwheat trials of 2019 and 2020 were performed at the same place with no intercrop between the trials. Fertilization $(700 \mathrm{~kg} / \mathrm{ha}$, 77 units of $\mathrm{P}_{2} \mathrm{O}_{5}$ and 77 units of $\mathrm{K}_{2} \mathrm{O}$ ) was provided before the sowing, respectively, on 11 April 2019 and 5 June 2020. The weather conditions (temperatures, rain, light irradiance, relative humidity) were measured daily at the weather station of the experimental farm of the university.

\subsection{Plant Description}

Two weeks before harvest, morphological observations were performed according to the Buckwheat Descriptor of IPGRI (International Plant Genetic Resources Institute) [40] on 10 plants per variety in 2019: plant height, number of nodes on the main stem, number of branches on the main stem, number of leaves per plant, number of inflorescences per plant, node of the first inflorescence, number of flowers per inflorescence, number of viable and aborted seeds per inflorescence. The aerial parts of five plants per variety were harvested and separated in stems, leaves and inflorescences and dry weights (DWs) were measured after $72 \mathrm{~h}$ oven drying at $70^{\circ} \mathrm{C}$. At harvest, yield parameters and thousand-grain weight were analyzed in 2019 and 2020.

\subsection{Nutritional Qualities of the Seeds}

Three replicates of 100 seeds per variety were crushed in liquid nitrogen to quantify mineral ( $\mathrm{Na}, \mathrm{Ca}, \mathrm{K}, \mathrm{Mg}, \mathrm{Cu}, \mathrm{Zn}, \mathrm{Fe})$ concentrations, protein content, amino acid composition and total polyphenols and flavonoids concentrations on the harvest of 2019.

For mineral content, seeds were digested with $4 \mathrm{~mL} \mathrm{HNO}_{3} 68 \%$ at $80{ }^{\circ} \mathrm{C}$. After complete evaporation, residues were dissolved with $\mathrm{HNO}_{3} 68 \%+\operatorname{HClcc}(1: 3, \mathrm{v}: \mathrm{v})$ and filtered on Whatman Grade A filter before quantification by flame atomic absorption spectrophotometry (ICE 3300, Thermo Scientific, Waltham, MA, USA) using standards (Spectracer-CPACHEM; accredited through ISO/IEC17025).

Total protein content was determined by analyzing the total nitrogen matter according to the Kjeldhal method [41] from $1 \mathrm{~g}$ of seed samples in triplicates. Amino acid profile and concentrations were determined according to Meussen et al. [42] from $200 \mathrm{mg}$ of grounded seeds in triplicates after acid hydrolysis and derivatization using phthaldialdehyde (OPA) reagent in combination with 9-fluorenylmethyl chloroformate (FMOC). Samples were exposed to $500 \mu \mathrm{L}$ of $6 \mathrm{M}$ hydrochloric acid containing $1 \%(w / v)$ of phenol and incubated during $18 \mathrm{~h}$ at $110{ }^{\circ} \mathrm{C}$. After drying under vacuum, samples were resuspended in $400 \mu \mathrm{L}$ methanol $+500 \mu \mathrm{L}$ MilliQwater. A double derivatization process was performed in pre- 
columns using (i) 2-mercaptoethanol 4\% + $25 \mathrm{mg}$ OPA dissolved in $0.5 \mathrm{~mL}$ methanol in a total volume of $5 \mathrm{~mL}$ borate buffer $\mathrm{pH} 10.4$ and (ii) FMOC $0.25 \%$ in acetonitrile. Samples were injected on a Zorbax Eclipse Plus column (Agilent; $3.5 \mu \mathrm{m}$ particle size; $150 \times 21 \mathrm{~mm})$ maintained at $40^{\circ} \mathrm{C}$. The mobile phase was composed of (A) phosphate buffer $40 \mathrm{mM} \mathrm{pH} 8.4$ and (B) acetonitrile/methanol/water (45:45:10 v/v/v)) at a flow rate of $0.42 \mathrm{~mL} \mathrm{~min}^{-1}$ (100\% A-0\% B $0.5 \mathrm{~min}$; progressive increase from 0 to 57\% B 0.5-25 min). OPA-derivatized and FMOC-derivatized amino acids were, respectively, detected at 350 $\mathrm{nm}$ and $260 \mathrm{~nm}$ excitation and $450 \mathrm{~nm}$ and 325 emission wavelengths. Bovine serum albumin (BSA: $1 \mathrm{mg} \mathrm{mL}^{-1}$ ) was used as standard.

Total polyphenols and flavonoids concentrations were quantified as previously described [13] from $100 \mathrm{mg}$ of grounded seeds in triplicates after extraction in $80 \%$ methanol. Total phenolic content was determined using the modified Folin-Ciocalteu colorimetric method and absorbances were measured at $760 \mathrm{~nm}$ using a spectrophotometer (UV1800, Shimadzu, s-Hertogenbosh, the Netherlands) and a standard curve ranging from 0.0 to $800.0 \mu \mathrm{g}$ of gallic acid $\mathrm{mL}^{-1}$. Total flavonoid content was determined by using the aluminum chloride chelation method, and absorbances were measured at $440 \mathrm{~nm}$ using a spectrophotometer (UV1800, Shimadzu, s-Hertogenbosh, the Netherlands) and a standard curve ranging from 0.0 to $50.0 \mu \mathrm{g}$ of quercetin $\mathrm{mL}^{-1}$.

\subsection{Statistical Analyses}

Analyses were conducted in R studio or SAS Enterprise Guide 8.3. The normality of the data was estimated using Shapiro-Wilk tests, and homoscedasticity was verified using Levene's tests. Morphological parameters were compared between species and varieties using a mixed linear model with the species or variety as fixed factor and the plot as random factor. Nutritional parameters were compared between species and varieties using one-way analysis of variance with the species or variety as fixed factor. Post-hoc comparison between varieties were performed using Tukey test. Principal component analysis was performed to visualize the differences in seed nutritional quality according to the varieties. If not indicated otherwise, data are presented as means \pm SD.

\section{Conclusions}

Common and Tartary buckwheat were grown in Belgium under field conditions and compared regarding growth parameters and seed nutritional qualities. Both species differed by their architecture mainly regarding the number of branches, the number of inflorescences per plant, the number of flowers per inflorescence and the seed weight. High yields were obtained for both species compared to other European countries despite the dry and hot periods observed over these last few years during spring and summer. We confirmed the nutritional qualities of the seeds regarding protein, amino acid, mineral content and flavonoids content. Both species differed by their seed quality, mainly in relation to the total protein content, which was higher in F. esculentum, and flavonoid, $\mathrm{Zn}$ and Fe contents, which were higher in F. tataricum.

Supplementary Materials: The following are available online at https:/ / www.mdpi.com/2223-7 747/10/2/258/s1, Figure S1: Weather conditions in the field in 2019 and 2020 during buckwheat culture in Corroy-le-Grand, Belgium. (a,b) Temperature and precipitations and (c,d) light irradiance on $(a, c) 2019$ and $(c, d) 2020$. Sowing and harvest dates are indicated by red vertical bars.

Author Contributions: Conceptualization, M.Q., G.J. and L.A.; methodology, L.A., C.D., G.J. and M.Q.; formal analysis, L.A. and M.Q.; investigation, L.A., C.D.; writing-original draft preparation, L.A. and M.Q.; writing-review and editing, C.D., G.J. and M.Q.; supervision, M.Q.; project administration, M.Q. All authors have read and agreed to the published version of the manuscript.

Funding: This research was funded by PINT-BILAT-M, grant number R.M010.19.

Data Availability Statement: The data presented in this study are available in the text and supplemental data. The data presented in this study are available on request from the corresponding author. 
Acknowledgments: The authors are grateful to Christiane Lynn F. Sia and Hélène Dailly for technical support and to Luc Van de Steene and Philippe Hamiet for field experiment support. The authors thank Ivan Larondelle for access to his lab for protein analysis. The authors are grateful to Ivan Kreft and to Christian Zewen for providing the seeds. Amino acid analyses were performed at the MOCA platform of UClouvain. Field trials were performed at the FERM platform of UCLouvain.

Conflicts of Interest: The authors declare no conflict of interest. The funders had no role in the design of the study; in the collection, analyses, or interpretation of data; in the writing of the manuscript, or in the decision to publish the results.

\section{References}

1. Campbell, C.G. Buckwheat: Fagopyrum esculentum Moench; Promoting the Conservation and Use of Underutilized and Neglected Crops, 19; International Plant Genetic Resources Institute: Rome, Italy, 1997; pp. 1-95.

2. Christa, K.; Soral-Śmietana, M. Buckwheat Grains and Buckwheat Products-Nutritional and Prophylactic Value of Their Components-A Review. Czech J. Food Sci. 2008, 26, 153-162. [CrossRef]

3. Small, E. 54. Buckwheat-The World's Most Biodiversity-Friendly Crop? Biodiversity 2017, 18, 108-123. [CrossRef]

4. Jacquemart, A.-L.; Cawoy, V.; Kinet, J.-M.; Ledent, J.-F.; Quinet, M. Is Buckwheat (Fagopyrum esculentum Moench) Still a Valuable Crop Today? Eur. J. Plant Sci. Biotechnol. 2012, 6, 1-10.

5. Murai, M.; Ohnishi, O. Population Genetics of Cultivated Common Buckwheat, Fagopyrum esculentum Moench. X. Diffusion Routes Revealed by RAPD Markers. Genes Genet. Syst. 1996, 71, 211-218. [CrossRef] [PubMed]

6. Mizuno, N.; Yasui, Y. Gene Flow Signature in the S-Allele Region of Cultivated Buckwheat. BMC Plant Biol. $2019,19,125$. [CrossRef] [PubMed]

7. Zhang, K.; He, M.; Fan, Y.; Zhao, H.; Gao, B.; Yang, K.; Li, F.; Tang, Y.; Gao, Q.; Lin, T. Resequencing of Global Tartary Buckwheat Accessions Reveals Multiple Domestication Events and Key Loci Associated with Agronomic Traits. Genome Biol. $2020,22,23$.

8. Bekkering, C.S.; Tian, L. Thinking Outside of the Cereal Box: Breeding Underutilized (Pseudo)Cereals for Improved Human Nutrition. Front. Genet. 2019, 10. [CrossRef] [PubMed]

9. Koval, D.; Plocková, M.; Kyselka, J.; Skřivan, P.; Sluková, M.; Horáčková, Š. Buckwheat Secondary Metabolites: Potential Antifungal Agents. J. Agric. Food Chem. 2020, 68, 11631-11643. [CrossRef]

10. Martínez-Villaluenga, C.; Peñas, E.; Hernández-Ledesma, B. Pseudocereal Grains: Nutritional Value, Health Benefits and Current Applications for the Development of Gluten-Free Foods. Food Chem. Toxicol. 2020, 137, 111178. [CrossRef]

11. Rodríguez, J.P.; Rahman, H.; Thushar, S.; Singh, R.K. Healthy and Resilient Cereals and Pseudo-Cereals for Marginal Agriculture: Molecular Advances for Improving Nutrient Bioavailability. Front. Genet. 2020, 11. [CrossRef]

12. FAOSTAT. Available online: http://www.fao.org/faostat/en/\#data/QC/visualize (accessed on 22 December 2020).

13. Aubert, L.; Konrádová, D.; Kebbas, S.; Barris, S.; Quinet, M. Comparison of High Temperature Resistance in Two Buckwheat Species Fagopyrum esculentum and Fagopyrum tataricum. J. Plant Physiol. 2020, 251, 153222. [CrossRef] [PubMed]

14. Aubert, L.; Konrádová, D.; Barris, S.; Quinet, M. Different Drought Resistance Mechanisms between Two Buckwheat Species Fagopyrum esculentum and Fagopyrum tataricum. Physiol. Plant. 2020, 13248. [CrossRef] [PubMed]

15. Siracusa, L.; Gresta, F.; Sperlinga, E.; Ruberto, G. Effect of Sowing Time and Soil Water Content on Grain Yield and Phenolic Profile of Four Buckwheat (Fagopyrum esculentum Moench.) Varieties in a Mediterranean Environment. J. Food Compos. Anal. 2017, 62, 1-7. [CrossRef]

16. Schulte auf'm Erley, G.; Kaul, H.-P.; Kruse, M.; Aufhammer, W. Yield and Nitrogen Utilization Efficiency of the Pseudocereals Amaranth, Quinoa, and Buckwheat under Differing Nitrogen Fertilization. Eur. J. Agron. 2005, 22, 95-100. [CrossRef]

17. Strahm, S.; Füglistaller, D.; Lädrach, C.; Enggist, A.; Thuet, A.; Luginbühl, C.; Ramseier, H.; Hiltbrunner, J. Growing Buckwheat in Switzerland: New Varieties for an Old Niche Crop. Agrar. Schweiz 2019, 10, 198-205.

18. Kreft, I.; Zhou, M.; Golob, A.; Germ, M.; Likar, M.; Dziedzic, K.; Luthar, Z. Breeding Buckwheat for Nutritional Quality. Breed Sci. 2020, 70, 67-73. [CrossRef]

19. Ahmed, A.; Khalid, N.; Ahmad, A.; Abbasi, N.A.; Latif, M.S.Z.; Randhawa, M.A. Phytochemicals and Biofunctional Properties of Buckwheat: A Review. J. Agric. Sci. 2014, 152, 349-369. [CrossRef]

20. Alvarez-Jubete, L.; Arendt, E.K.; Gallagher, E. Nutritive Value of Pseudocereals and Their Increasing Use as Functional Gluten-Free Ingredients. Trends Food Sci. Technol. 2010, 21, 106-113. [CrossRef]

21. Zhu, F. Chemical Composition and Health Effects of Tartary Buckwheat. Food Chem. 2016, 203, 231-245. [CrossRef]

22. Huda, M.N.; Lu, S.; Jahan, T.; Ding, M.; Jha, R.; Zhang, K.; Zhang, W.; Georgiev, M.I.; Park, S.U.; Zhou, M. Treasure from Garden: Bioactive Compounds of Buckwheat. Food Chem. 2021, 335, 127653. [CrossRef]

23. Eggum, B.O.; Kreft, I.; Javornik, B. Chemical Composition and Protein Quality of Buckwheat (Fagopyrum esculentum Moench). Plant Food Hum. Nutr. 1980, 30, 175-179. [CrossRef]

24. Giménez-Bastida, J.A.; Zieliński, H. Buckwheat as a Functional Food and Its Effects on Health. J. Agric. Food Chem. 2015, 63, 7896-7913. [CrossRef] [PubMed]

25. Yilmaz, H.Ö.; Ayhan, N.Y.; Meriç, Ç.S. Buckwheat: A Useful Food and Its Effects on Human Health. Curr. Nutr. Food Sci. 2020, 16, 29-34. [CrossRef] 
26. Bellaloui, N.; McClure, A.M.; Mengistu, A.; Abbas, H.K. The Influence of Agricultural Practices, the Environment, and Cultivar Differences on Soybean Seed Protein, Oil, Sugars, and Amino Acids. Plants 2020, 9, 378. [CrossRef] [PubMed]

27. Podolska, G.; Górecka, D.; Russel, H.; Dziedzic, K.; Boguszewska, E. Abiotic Stress Affects the Yield and Nutrients of Buckwheat Grains. Zemdirbyste 2019, 106, 233-240. [CrossRef]

28. Halbrecq, B.; Romedenne, P.; Ledent, J.F. Evolution of Flowering, Ripening and Seed Set in Buckwheat (Fagopyrum esculentum Moench): Quantitative Analysis. Eur. J. Agron. 2005, 3, 209-224. [CrossRef]

29. Bavec, F.; Pusnik, S.; Rajcan, I. Yield Performance of Two Buckwheat Genotypes Grown as a Full-Season and Stubble-Crop. Rostl. Vyrob. 2002, 48, 351-355. [CrossRef]

30. Golob, A.; Stibilj, V.; Kreft, I.; Germ, M. The Feasibility of Using Tartary Buckwheat as a Se-Containing Food Material. J. Chem. 2015, 2015, 246042. [CrossRef]

31. Luthar, Z. New varieties of buckwheat and antioxidant content. In Proceedings of the Novi Izzivi v Agronomiji 2019, Laško, Slovenia, 31 January-1 February 2019; pp. 118-124.

32. Cawoy, V.; Ledent, J.-F.; Kinet, J.-M.; Jacquemart, A.-L. Floral Biology of Common Buckwheat (Fagopyrum esculentum Moench). Eur. J. Plant Sci. Biotechnol. 2009, 3, 1-9.

33. Wu, L.-Y.; Wang, B.; Schoen, D.J.; Huang, S.-Q. Transitions from Distyly to Homostyly Are Associated with Floral Evolution in the Buckwheat Genus (Fagopyrum). Am. J. Bot. 2017, 104, 1232-1240. [CrossRef]

34. Popović, V.; Sikora, V.; Berenji, J.; Filipović, V.; Dolijanović, Ž.; Ikanović, J.; Dončić, D. Analysis of Buckwheat Production in the World and Serbia. Econ. Agric. 2014, 61,1-10. [CrossRef]

35. Brunori, A.; Brunori, A.; Baviello, G.; Marconi, E.; Colonna, M.; Ricci, M. The Yield of Five Buckwheat (Fagopyrum esculentum Moench) Varieties Grown in Central and Southern Italy. Fagopyrum 2005, 22, 98-102.

36. Gavric, T.; Cadro, S.; Gadzo, D.; Djikic, M.; Bezdrob, M.; Jovovic, Z.; Jurkovic, J.; Hamidovic, S. Influence of Meteorological Parameters on the Yield and Chemical Composition of Common Buckwheat (Fagopyrum esculentum Moench). Agric. Cult. For. 2018, 64. [CrossRef]

37. Qin, P.; Wang, Q.; Shan, F.; Hou, Z.; Ren, G. Nutritional Composition and Flavonoids Content of Flour from Different Buckwheat Cultivars. Int. J. Food Sci. Technol. 2010, 45, 951-958. [CrossRef]

38. Ge, R.H.; Wang, H. Nutrient Components and Bioactive Compounds in Tartary Buckwheat Bran and Flour as Affected by Thermal Processing. Int. J. Food Prop. 2020, 23, 127-137. [CrossRef]

39. Pongrac, P.; Vogel-Mikuš, K.; Jeromel, L.; Vavpetič, P.; Pelicon, P.; Kaulich, B.; Gianoncelli, A.; Eichert, D.; Regvar, M.; Kreft, I. Spatially Resolved Distributions of the Mineral Elements in the Grain of Tartary Buckwheat (Fagopyrum tataricum). Food Res. Int. 2013, 54, 125-131. [CrossRef]

40. IPGRI. Descriptors for Buckwheat (Fagopyrum Spp.); International Plant Genetics Resources: Rome, Italy, 1994; ISBN 978-92-9043221-0.

41. Kjeldahl, J. Neue Methode Zur Bestimmung Des Stickstoffs in Organischen Korpern. Z. Fur. Anal. Chem. 1883, 366-382. [CrossRef]

42. Meussen, B.J.; van Zeeland, A.N.T.; Bruins, M.E.; Sanders, J.P.M. A Fast and Accurate UPLC Method for Analysis of Proteinogenic Amino Acids. Food Anal. Methods 2014, 7, 1047-1055. [CrossRef] 